均質化結晶塑性有限要素法に基づく数值二軸引張試験を

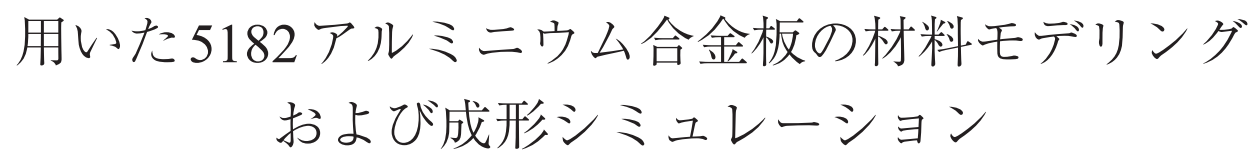

山中 晃徳 $*$. 橋本 圭右 $* *$.川口 順平 $* * *$ 櫻井 健夫 $* * * *$. 桑原 利彦*

Journal of The Japan Institute of Light Metals, Vol. 65, No. 11 (2015), 561-567

(C) 2015 The Japan Institute of Light Metals

\title{
Material modeling and forming simulation of 5182 aluminum alloy sheet using numerical biaxial tensile test based on homogenized crystal plasticity finite element method
}

\author{
Akinori YAMANAKA*, Keisuke HASHIMOTO**, Junpei KAWAGUCHI*** \\ Takeo SAKURAI**** and Toshihiko KUWABARA*
}

\begin{abstract}
This paper proposes a material modeling methodology of sheet metals using a numerical biaxial tensile test based on the crystal plasticity finite element (CPFE) method and the mathematical homogenization method. To demonstrate the feasibility of the proposed methodology, the biaxial tensile deformation behavior of 5182 aluminum alloy sheet was predicted by the numerical biaxial tensile tests of the sheet. The stress-strain curves and the shapes of the contours of plastic work calculated by the numerical biaxial tensile tests were quantitatively verified by the experimental biaxial tensile test using the cruciform specimen. Parameters of the Yld2000-2d yield function were identified using the results of experimental and numerical biaxial tensile tests. For comparison, von Mises's and Hill's yield functions were identified using the experimental data. To elucidate the effects of the yield functions on the accuracy of sheet metal forming simulation, finite element simulations of hydraulic bulge forming were performed using the identified yield functions. The simulation results demonstrated that the forming simulation using the Yld2000-2d yield function identified by the numerical biaxial tensile tests showed better accuracy than that of the Mises's and Hill's yield functions and was comparable to that of the Yld2000-2d yield function calibrated experimentally.
\end{abstract}

(Received May 18, 2015 Accepted August 3, 2015)

Keywords: numerical biaxial tensile test, crystal plasticity finite element method, 5000 series aluminum alloy sheet, material modeling

1. 緒言

近年，自動車車体への適用が進むアルミニウム合金板は， 鋼板と比較して加工性が低く，プレス成形加工中に割れやし わが発生しやすい ${ }^{1), 2)}$ 。そのため, アルミニウム合金板のプ レス成形加工においては，金型作製コストの削減，成形不具 合の予測を目的として，有限要素法を用いた成形シミュレー ションの利用が活発となっており，成形シミュレーションの
予測精度のさらなる向上が求められている3)。

成形シミュレーションにより高精度に加工不具合を予測す るためには，成形シミュレーションに用いる材料モデルが実 際の材料の弾塑性変形挙動を再現できることが求められる。 特に, 実際のプレス成形では, 板材は多軸応力下で変形する ため, シミュレーションに用いる材料モデルは, 単軸応力状 態のみならず多軸応力状態での材料の弾塑性变形挙動を忠実 に再現できるものでなければならない吕。Kuwabaraら ${ }^{5)}$ は,

*東京農工大学大学院工学研究院先端機械システム工学部門（テ184-8588 東京都小金井市中町2-24-16） Division of Advanced Mechanical Systems Engineering, Institute of Engineering, Tokyo University of Agriculture and Technology (2-24-16 Nakacho, Koganei-shi, Tokyo 184-8588) E-mail: a-yamana@cc.tuat.ac.jp

**東京農工大学大学院工学府機械システム工学専攻大学院生 (小金井市)〔現在：古河ロックドリル株式会社開発設計部（高崎 市)] Department of Mechanical Systems Engineering, Graduate School of Engineering, Tokyo University of Agriculture and Technology (Koganei-shi, Tokyo)〔Present: Development and Engineering Department, Furukawa Rock Drill Co., Ltd. (Takasaki-shi, Gunma)〕

***東京農工大学大学院工学府機械システム工学専攻大学院生（小金井市）〔現在：近畿車両株式会社（東大阪市） Department of Mechanical Systems Engineering, Graduate School of Engineering, Tokyo University of Agriculture and Technology (Koganei-shi, Tokyo)〔Present: The Kinki Sharyo, Co., Ltd. (Higashi-Osaka-shi, Osaka]

****株式会社神戸製鋼所アルミ・銅事業部門（東京都） Aluminum and Copper Business, KOBE STELL, LTD. (Shinagawa-ku, Tokyo) 
十字形試験片を用いた二軸引張試験法を開発し，この試験方 法によって得られた等塑性仕事面に基づいて適切な材料モデ ル（降伏関数）を決定することが可能であることを示した。 さらに, 彌永ら ${ }^{6)}$ は 6000 系アルミニウム合金板に対して, また本特集号において桑原ら ${ }^{7)}$ は5000系アルミニウム合金 板に対して等塑性仕事面の形状を良好に再現する Yld2000-2d 降伏関数 ${ }^{8)}$ を同定し，それを用いた成形シミュレーション の実験的検証を行うことでシミュレーションの予測精度が向 上することを報告している。しかしながら，現象論的な降伏 関数を用いた成形シミュレーションにおいて，集合組織の違 いによる板材の変形挙動の差異を表現するためには，異なる 降伏関数を同定する必要がある ${ }^{9)}$ 。また，適切な降伏関数や 材料パラメータを決定するためには，複数回の二軸引張試験 の実施を必要とする。

一方で，結晶塑性理論に基づく材料モデルすなわち多結晶 塑性モデルを用いた有限要素シミュレーションでは，集合組 織の情報を材料の内部状態を表す変数として直接考慮する ことが可能である。Nakamachi ら ${ }^{10)}$ ，Xieら ${ }^{11)}$ およびRaabe $ら^{12)}$ は, 結晶塑性有限要素法を用いて, 金属板材の球頭絞 りや深絞りなどの成形加工における集合組織に依存した変形 挙動を解析する計算手法を提案している。しかしながら，多 結晶塑性モデルを用いた成形シミュレーションは，大きな計 算コストを必要とするため, 産業界への普及は現在のところ は困難であると言ってよいであろう。

多結晶塑性モデルのもう一つの利用方法として, 多結晶塑 性モデルを用いて材料の多軸変形挙動を解析する仮想的な材 料試験のシミュレーションを行い，そのシミュレーション結 果に基づいて降伏関数を同定し，同定した降伏関数を成形シ ミュレーションに適用するという方法がある ${ }^{13)}$ 。しかしな がら，この方法で高精度な成形シミュレーションの結果を得 るためには，当然ながら，仮想的な材料試験に用いる多結晶 塑性モデルや材料パラメータが実材料の変形挙動を忠実に再 現できるものでなければならない。これに対して，著者らは 前報 ${ }^{14)}$ において, 数学的均質化法に基づく結晶塑性有限要 素法を用いた二軸引張変形シミュレーション方法を提案し, 5000 系アルミニウム合金板材 A5182-O材の二軸引張変形挙 動の解析に適用した。また, EBSD測定によって得られた板 材の結晶方位と単軸引張試験結果に基づいて同定した結晶塑 性モデルのパラメータを用いたシミュレーションを実施すれ ば，十字形試験片を用いた二軸引張試験で得られる等塑性仕 事面とその形状変化を比較的良好に再現できることを示し た。

本研究では, 前報 ${ }^{14)}$ で提案した数学的均質化法に基づく 結晶塑性有限要素法を用いた仮想的な二軸引張試験（数值二 軸引張試験）による材料モデリング方法を提案する。本論 文では，まず数值二軸引張試験によるアルミニウム合金板 A5182-O材の二軸応力下に㧈ける弾塑性変形挙動，特に等塑
性仕事面と塑性ひずみ速度の方向の予測結果を示す。次に, 数值二軸引張試験の結果を, 十字形試験片を用いた二軸引張 試験結果と比較検証したうえで，予測された等塑性仕事面に 基づいて同定した降伏関数を示す。さらに，同定した降伏関 数を用いた液圧バルジ成形シミュレーションを実施し，その 計算結果を液圧バルジ試験の結果と比較することによって, 本研究で提案する数值二軸引張試験による材料モデリング方 法の有用性を示す。

\section{2. 供 試 材}

本研究で用いた供試材は， 前報 ${ }^{14)}$ と同じアルミニウム合 金板 A5182-O材であり，初期平均板厚は $1.0 \mathrm{~mm}$ である。供 試材の化学成分を Table 1 に示す。供試材の結晶方位を取得 するため, 前報 ${ }^{14)}$ での測定領域よりも板厚方向に広い, 板 厚断面の $1000 \times 857 \mu \mathrm{m}^{2}$ （圧延方向 $\times$ 板厚方向）の領域にお いて EBSD測定を行い，1,009,957個の結晶方位データを取 得した。Fig. 1 に，得られた結晶方位より作成した $\{111\}$ 極点図を示す。また，Fig. 2 に方位分布関数（Orientation

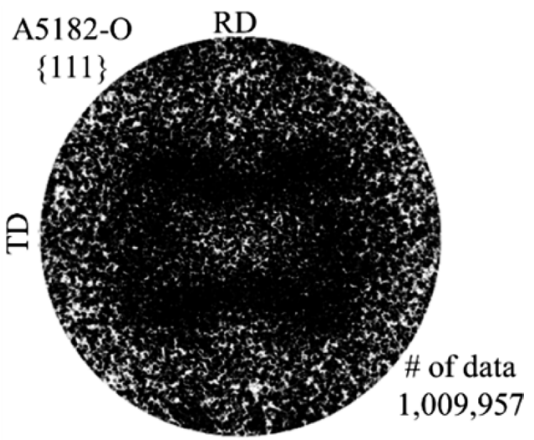

Fig. $1\{111\}$ pole figure of crystal orientation distribution in the A5182-O aluminum alloy sheet.

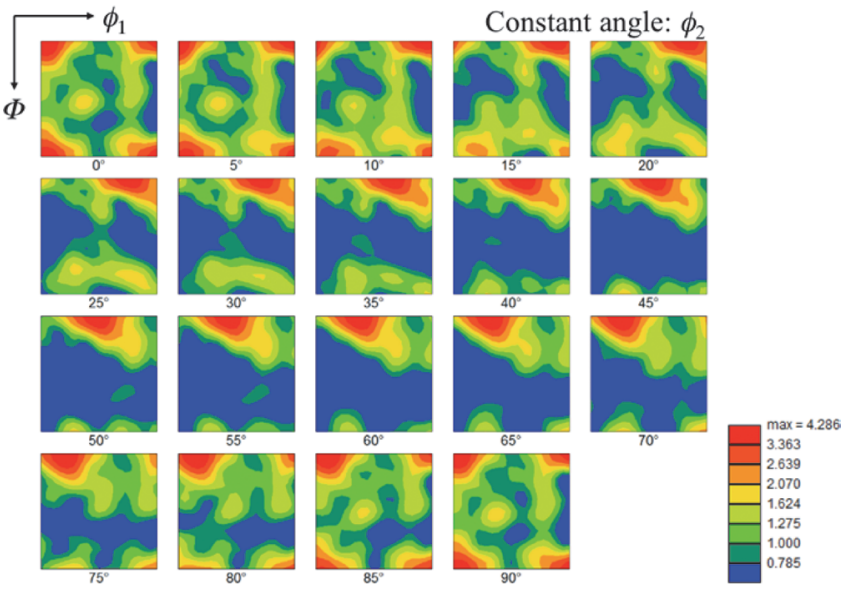

Fig. 2 Orientation distribution function of A5182-O aluminum alloy sheet measured by EBSD.

Table 1 Chemical composition of A5182-O aluminum alloy sheet (mass\%).

\begin{tabular}{l|c|c|c|c|c|c|c|c|c}
\hline \hline & $\mathrm{Si}$ & $\mathrm{Fe}$ & $\mathrm{Cu}$ & $\mathrm{Mn}$ & $\mathrm{Mg}$ & $\mathrm{Cr}$ & $\mathrm{Zn}$ & $\mathrm{Ti}$ & $\mathrm{Al}$ \\
\hline A5182-O aluminum alloy sheet & 0.09 & 0.17 & 0.02 & 0.23 & 4.55 & 0.03 & 0.02 & 0.01 & $\mathrm{Rem}$. \\
JIS standard & $\leq 0.20$ & $\leq 0.35$ & $\leq 0.15$ & $0.20-0.5$ & $4.0-5.0$ & $\leq 0.10$ & $\leq 0.25$ & $\leq 0.10$ & $\mathrm{Rem}$. \\
\hline
\end{tabular}


Distribution Function; ODF）を示す。本研究で取得したODF は，前報 ${ }^{14)}$ とは測定範囲が異なるため，完全に一致する結 果とはなっていない。また，本供試材はCube方位にやや配 向しており，R方位や圧延方向（RD）回転や板厚方向（ND） 回転したCube方位も含む材料であることを確認した。本研 究では, 供試材の単軸引張試験および十字形試験片を用いた 二軸引張試験を実施したが，これらの実験方法および条件に ついては前報 ${ }^{14)}$ と同様である。

\section{3. シミュレーション方法}

本研究では, 前報 ${ }^{14)}$ と同様にPeirce ${ }^{15)}$ によって提案さ れた単結晶の結晶塑性理論に基づく結晶塑性有限要素法を用 いて数值二軸引張試験および単軸引張変形シミュレーショ ン (以後, 数值単軸引張試験と呼ぶ) を行う。定式の詳細は, 前報 ${ }^{14)}$ を参照されたいが，数值単軸引張試験による結晶塑 性モデルのパラメータ同定および数值二軸引張試験結果の説 明のために，本研究で用いた加工硬化則を以下に示す。

本研究では，すべり系 $\alpha$ におけるせん断ひずみ速度 $\dot{\gamma}^{(\alpha)}$ 表現するために, 次式に示すPan ${ }^{16)}$ が提案するひずみ速 度依存型の指数則を用いる。

$$
\dot{\gamma}^{(\alpha)}=\dot{\gamma}_{0} \frac{\tau^{(\alpha)}}{g^{(\alpha)}}\left|\frac{\tau^{(\alpha)}}{g^{(\alpha)}}\right|^{\frac{1}{m}-1}
$$

ここで， $\dot{\gamma}_{0}$ は基準せん断ひずみ速度， $\tau^{(\alpha)}$ は分解せん断応力, $m$ はひずみ速度感受性指数である。 $g^{(\alpha)}$ は臨界分解せん断応 力であり，その時間発展すなわち加工硬化則は次式を用い た。

$$
\begin{gathered}
g^{(\alpha)}=\tau_{0}+\int_{t} \dot{g}^{(\alpha)} d t \\
\dot{g}^{(\alpha)}=\sum_{(\beta)} h^{(\alpha \beta)}\left|\dot{\gamma}^{(\beta)}\right|
\end{gathered}
$$

ここで， $\tau_{0}$ は初期臨界分解せん断応力， $h^{(\alpha \beta)}$ はすべり系 $\beta$ が すべり系 $\alpha$ の硬化に及ぼす寄与を規定する硬化係数行列であ り, Hutchinson ${ }^{17)}$ やAsaro ${ }^{18)}$ が提案した次式を用いる。

$$
h^{(\alpha \beta)}=q h(\gamma)+(1-q) h(\gamma) \delta_{\alpha \beta}
$$

ここで， $\delta_{\alpha \beta}$ はクロネッカーのデルタ,$q$ は潜在硬化のレベル を表す係数である。本研究では，各すべり系は等方的に硬化 するものと仮定し， $q=1$ とした。また $h(\gamma)$ は次式に示す 蓄積せん断ひずみに関係づけられた次式の $n$ 乗硬化則を用い る $^{19)}$ 。

$$
\begin{gathered}
h(\gamma)=h_{0} n C\left\{C\left(\gamma_{0}+\gamma\right)\right\}^{n-1} \\
\gamma=\sum_{(\alpha)}\left|\gamma^{(\alpha)}\right|
\end{gathered}
$$

ここで, $h_{0}$ は初期硬化係数, $n$ は硬化指数, $C$ は硬化係数, $\gamma_{0}$ は初期せん断ひずみ， $\gamma$ は蓄積せん断ひずみである。前 報 ${ }^{14)}$ と同様, 単軸引張試験と数值単軸引張試験により得ら れる真応力-真ひずみ線図が一致するように，式(2) で用い る初期臨界分解せん断応力 $\tau_{0}$ および式 (5) で用いる材料パラ メータ $h_{0}, n, C, \gamma_{0}$ を同定した。

また，集合組織に依存する板材の巨視的な変形挙動や等塑 性仕事面を数学的に正確に算出するため，2 変数漸近展開近 似に基づく均質化法 ${ }^{20)}$ を用いて，微視的および巨視的空間
スケールに対する仮想仕事の原理式を導出した ${ }^{14), 21)}$

\section{4. シミュレーション条件}

本解析に用いた有限要素モデルおよび境界条件を Fig. 3 に 示す ${ }^{14)}$ 。直交デカルト座標系 $x_{i}(i=1,2,3)$ は, それぞれ板 材の圧延方向 (RD), 圧延直角方向 (TD), 板厚方向 (ND) と平行とする。マクロモデルには, $1 \times 1 \times 1 \mathrm{~mm}^{3}$ の 8 積分点を 有する 8 節点六面体アイソパラメトリック要素を 1 つ用いる。 このマクロモデルによって，巨視的な変形挙動を表現する。 一方，材料の集合組織を表現する有限要素モデルすなわち代 表体積要素（Representative Volume Element; RVE）は， $0.5 \times 0.5$ $\times 0.5 \mu \mathrm{m}^{3}$ の立方体であり, $0.1 \times 0.1 \times 0.1 \mu \mathrm{m}^{3}$ の六面体要素を用 いて $5 \times 5 \times 5$ の要素分割を行った。RVEに使用した要素はマク ロモデルと同じである。また，RVEを構成する有限要素の積 分点1つに1つの結晶方位を割り当てる。したがって, RVE 内に 1,000 個の結晶粒が内在していることを表現する。本研 究では, EBSDで得られた約 100 万個の結晶方位データから RVEの各積分点に割り当てる 1,000 個の結晶方位データを乱 数を用いて無作為に抽出した。Fig. 4 に，RVEに割り当てた 1,000 個の初期結晶方位の $\{111\}$ 極点図を示す。数值二軸引張 試験および数值単軸引張試験で用いたA5182-Oの物性值に ついても， 前報 ${ }^{14)}$ と同一である。

数值単軸引張試験では, 境界条件としてマクロモデルの $\mathrm{RD}$ に強制節点変位速度を与える。このときの公称ひずみ速 度は単軸引張試験条件 ${ }^{14)}$ と同じ $5.0 \times 10^{-4} \mathrm{~s}^{-1}$ となるように設 定する。一方, 数值二軸引張試験では, 境界条件としてマク ロモデルの RD と $\mathrm{TD}$ に強制節点力速度 $F_{1}, F_{2}$ を与える。この とき, 二軸引張試験と同様に各方向への真応力比が一定とな り, 数值単軸引張試験における塑性ひずみ速度と同程度とな るように強制節点力速度を設定する。

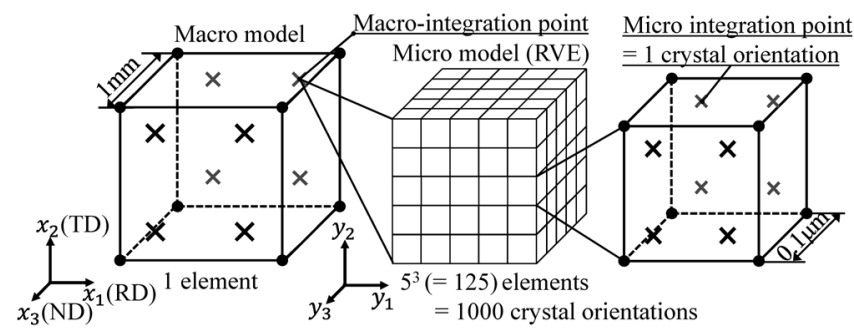

Fig. 3 Finite element models for macroscopic and microscopic scales ${ }^{14)}$.

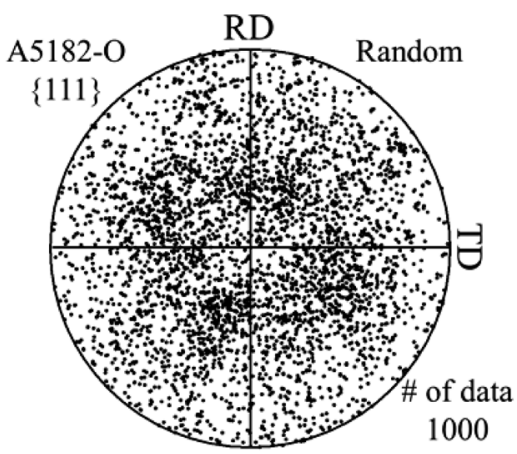

Fig. $4\{111\}$ pole figure of 1000 initial crystal orientations for the finite element simulations. 


\section{5. 数値単軸引張試験による材料パラメータの同定}

結晶塑性モデルの加工硬化則の材料パラメータを単軸引張 試験および数值単軸引張試験の結果が一致するように同定す る。Fig. 5 に, 数值単軸引張試験によって得られたRDを引 張方向とする真応力ー真ひずみ曲線を示す。図中のプロット 点は実験值, 実線が数值単軸引張試験の計算值を示してい る。このとき同定された材料パラメータを Table 2 に示す。

同定した材料パラメータを用いて, 引張方向を RDから $90^{\circ}(\mathrm{TD})$ および $45^{\circ}\left(\mathrm{RD} 45^{\circ}\right)$ 回転させて実施した数值単軸引 張試験で得られた真応力-真ひずみ曲線を，それぞれ Fig. 6

Table 2 Identified material parameters for the A5182-O aluminum alloy sheet.

\begin{tabular}{l|c}
\hline \hline Initial critical resolve shear stress, $\tau_{0}[\mathrm{MPa}]$ & 43.5 \\
Initial hardening coefficient, $h_{0}[\mathrm{MPa}]$ & 120 \\
Hardening component, $n$ & 0.24 \\
Hardening coefficient, $C$ & 17 \\
Initial shear strain, $\gamma_{0}$ & 0.1 \\
\hline
\end{tabular}

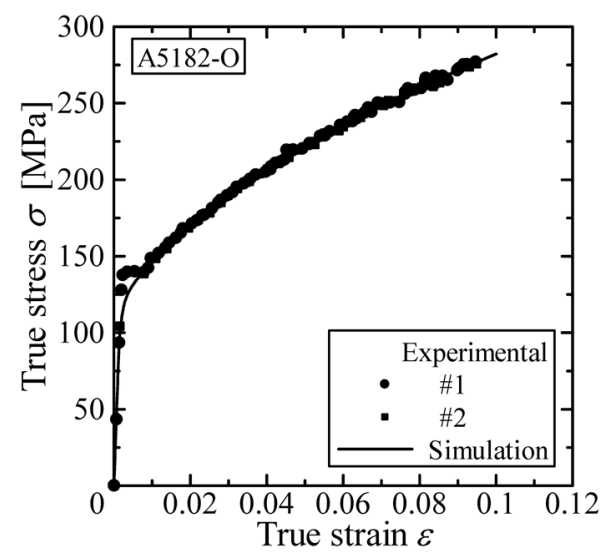

Fig. 5 True stress-true strain curves obtained by the experimental and the numerical uniaxial tensile tests. The tensile direction is rolling direction (RD).

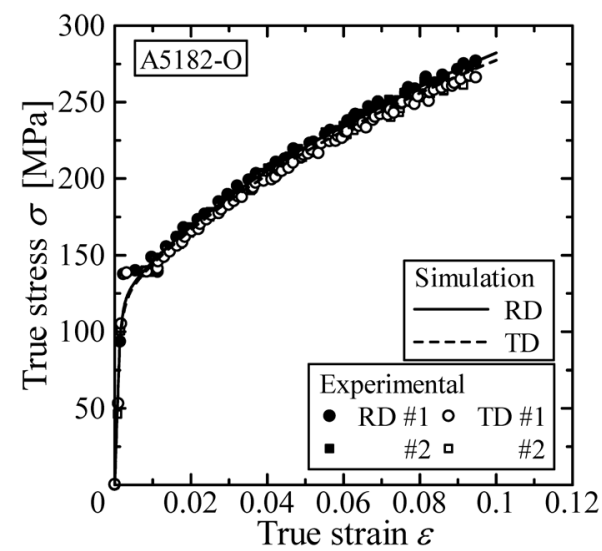

Fig. 6 True stress-true strain curves obtained by the experimental and the numerical tensile tests. The tensile direction is transvers direction (TD). For the comparison, the true stress-true strain curve in RD is inserted.
およびFig. 7 に示す。実験值は, TDの塑性流動応力はRDの 場合よりも低い值を示す。この傾向は, 数值単軸引張試験に おいても良好に再現できており, TDの塑性流動応力を定量 的に予測できることを示す結果である。また，RD45の塑性 流動応力の計算值は実験值よりも高く見積もったが, 比較的 良好に再現しているといえる。

Fig. 8 に, 数值単軸引張試験により計算された引張方向に 対するランクフォード $(r)$ 值の変化, およびその実験值を 示す。なお, $r$ 值は公称ひずみ 0.10 における板幅方向の塑 性ひずみを板厚方向の塑性ひずみで除することによって算 出した。Fig. 8 より, $r$ 值の実験值は $0^{\circ}(\mathrm{RD})$ で最も大きく, RD45で最小值を取り，TDで再び大きくなる傾向を示す。 一方, 計算值は, 引張方向がRDおよびRD45における $r$ 值 は，実験結果を良好に再現しているのに対し，TDにおいて は実験值よりも低く見積もる結果となった。

\section{6. 数値二軸引張試験}

数值二軸引張試験を行い, 得られた等塑性仕事面を実験結 果と比較する。Fig. 9に, 数值二軸引張試験における真応力 経路を示す。図中の破線は, 真応力比が一定となる線形応力 経路であり，実線が数值二軸引張試験における応力経路の 計算值である。真応力比一定の条件下で数值二軸引張試験が 行われていることを確認できる。以下では，基準塑性ひずみ

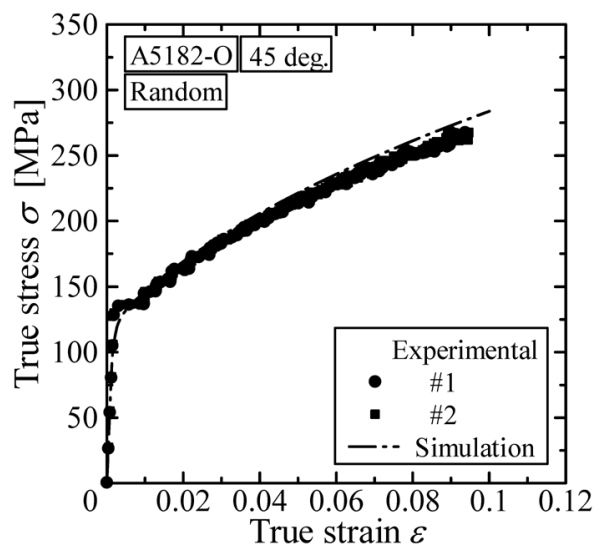

Fig. 7 True stress-true strain curves obtained by the experimental and the numerical tensile tests. The tensile direction is 45 degree against $\mathrm{RD}\left(\mathrm{RD} 45^{\circ}\right)$.

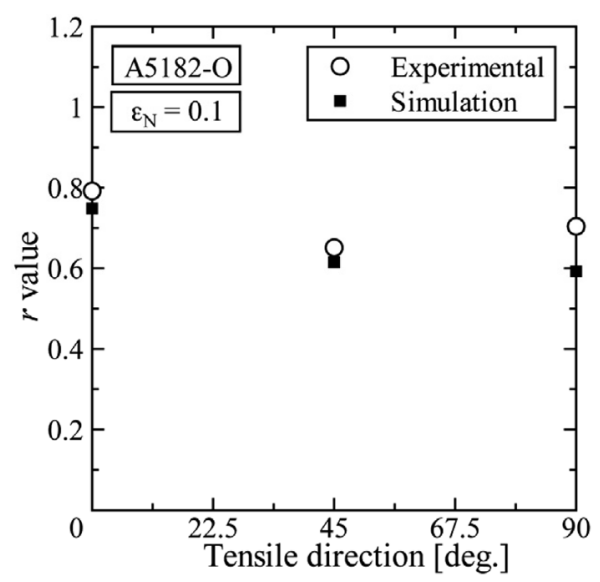

Fig. 8 Variation of $r$-value for tensile direction obtained by the experimental and the numerical biaxial tensile tests. 


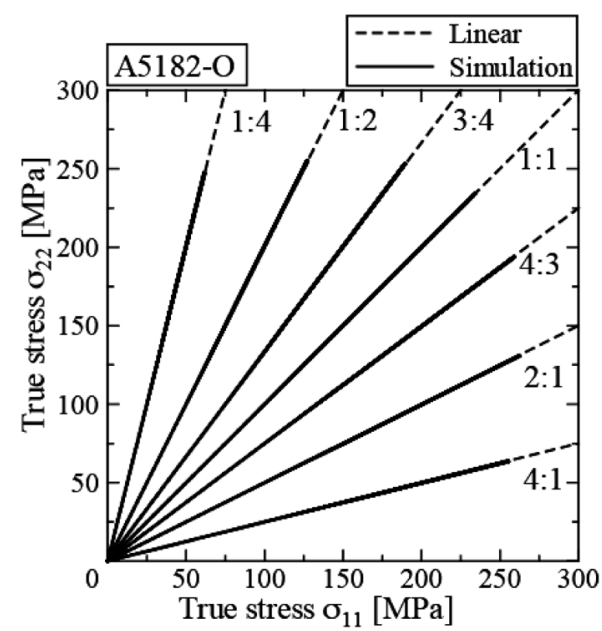

Fig. 9 True stress paths simulated by the numerical biaxial tensile tests and linear stress paths.

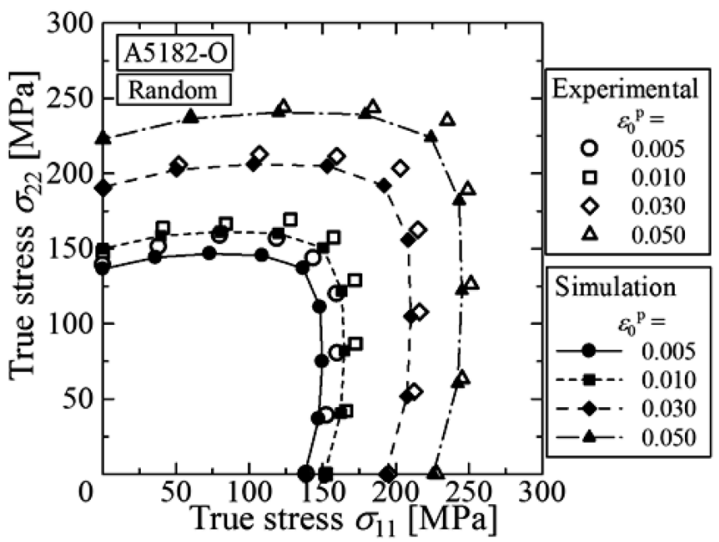

Fig. 10 Contours of equal plastic work obtained by the experimental and the numerical uni- and biaxial tensile tests.

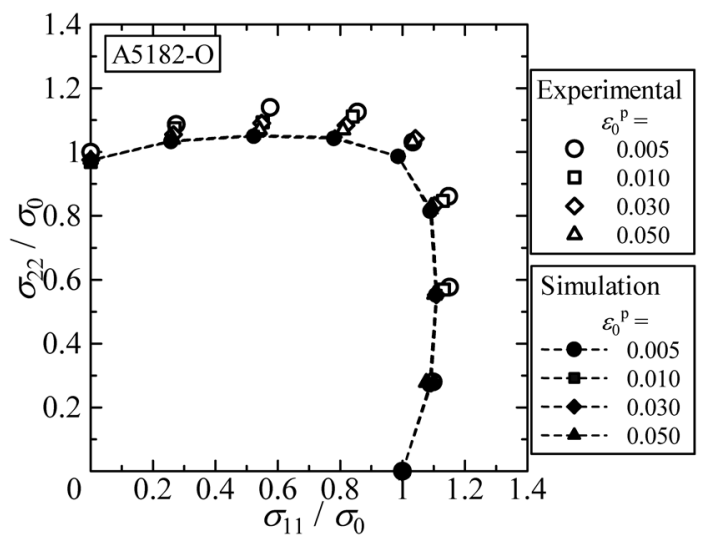

Fig. 11 Dimensionless contours of equal plastic work normalized by flow stress for uniaxial tensile tension along RD. $\varepsilon_{0}^{p}=0.05$ までの計算結果を実験結果と比較する。

Fig. 10 に, 数值二軸引張試験により算出した等塑性仕事面 および実験值を示す。白抜きのプロット点が実験值を示し， 線付きのプロット点がシミュレーション結果を示す。基準塑 性ひずみ $\varepsilon_{0}^{p}=0.005 に お い て は ，$ 全体的に計算值は実験值より も小さい值を示すが, 基準塑性ひずみの増大に伴い, その差 は小さくなる。また, 応力比が $3: 4$ と $1: 1$ となる応力経路の 等塑性仕事点は，他の応力比と比較しても計算值は実験值よ りも小さく見積もられるが，それ以外の応力経路ではシミュ レーションで得られた等塑性仕事面は実験結果と非常によく 一致する。

数值二軸引張試験で得られる等塑性仕事面の形状変化すな わち異方硬化挙動の再現精度を検証するために, 等塑性仕事 面を構成する応力点の值を各基準塑性ひずみでの応力比 $1: 0$ の真応力によって除することにより得られた無次元化等塑性 仕事面を Fig. 11 に示す。前報 ${ }^{14)}$ でも示したように，実験か ら得られた無次元化等塑性仕事面は, 応力比が $1: 1$ となる応 力経路を除き, 基準塑性ひずみの増大に伴って全体的に内側 に収縮するような異方硬化挙動を示す。これに対して，数值 二軸引張試験の結果は, 等塑性仕事面の形状は基準塑性ひず みが増大しても変化しない等方硬化挙動を示す。

\section{7. 材料モデリング}

数值二軸引張試験によって得られた等塑性仕事面に基づき Yld 2000-2d 降伏関数のパラメー夕 $\alpha_{1} \sim \alpha_{8}$ および次数 $M を$ 同 定する。 $\alpha_{1} \sim \alpha_{8}$ は, 数值単軸引張試験および数值二軸引張 試験により得られる材料特性值 $\sigma_{0}, \sigma_{45}, \sigma_{90}, \sigma_{b}, r_{0}, r_{45}, r_{90}, r_{b}$ と 降伏関数による予測值が一致するように 8 元連立非線形方程 式を解くことにより得る。ここで， $\sigma_{0}, \sigma_{45}, \sigma_{90}$ は, Fig. 5, Fig. 6 およびFig. 7 に示した RD, RD45およびTD方向の数值単軸 引張試験により得られた塑性流動応力であり， $r_{0}, r_{45}, r_{90}$ は, Fig. 8 に示したRD, RD45㧍よびTD方向の $r$ 值である。また, $\sigma_{b}, r_{b}$ は等二軸方向への引張試験によって得られた塑性流動 応力と塑性ひずみ速度比 $d \varepsilon_{22}^{p} / d \varepsilon_{11}^{p}$ である。一方, 次数 $M$ は等 塑性仕事面に対して降伏関数から計算される理論降伏曲面と の平均二乗誤差が最も小さくなるように決定した。なお，十 字形試験片を用いた二軸引張試験の結果から Yld2000-2d 降 伏関数を同定する方法も上記と同じである。

本研究で提案する数值二軸引張試験による材料モデリン グ手法の有用性を検証するため, 数值二軸引張試験結果 に基づき同定されるYld2000-2d 降伏関数（以後, Yld20002d (Sim.) と記す) と十字形試験片を用いた二軸引張試験で測 定される等塑性仕事面に基づいて同定したYld2000-2d降伏 関数（以後, Yld2000-2d (Exp.) と記す) のほかに，等方性 のvon Mises 降伏関数（以後, Mises と記す）および, Hillの 二次降伏関数 (以後, Hill'48 と記す) を同定した。Table 3 に, 同定したYld2000-2d（Sim.）およびYld2000-2d（Exp.）のパ

Table 3 Material parameters for Yld2000-2d yield functions at the reference logarithmic plastic strain of $\varepsilon_{0}^{p}=0.05$.

\begin{tabular}{l|c|c|c|c|c|c|c|c|c|c}
\hline \hline & $M$ & $\alpha_{1}$ & $\alpha_{2}$ & $\alpha_{3}$ & $\alpha_{4}$ & $\alpha_{5}$ & $\alpha_{6}$ & $\alpha_{7}$ & $\alpha_{8}$ \\
\hline Yld2000-2d (Sim.) & 7.24 & 0.998 & 0.939 & 0.985 & 1.034 & 1.006 & 0.967 & 0.953 & 1.057 \\
Yld2000-2d (Exp.) & 8.86 & 0.966 & 1.000 & 0.892 & 1.010 & 0.994 & 0.916 & 0.984 & 1.157 \\
\hline
\end{tabular}




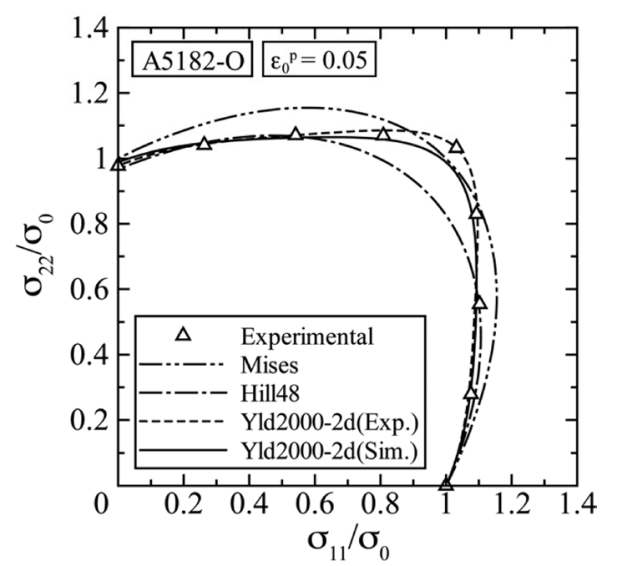

Fig. 12 Comparison of yield surfaces calculated by the identified yield functions with measured stress points comprising contours of equivalent plastic work for the reference plastic strain of $\varepsilon_{0}^{p}=0.05$.

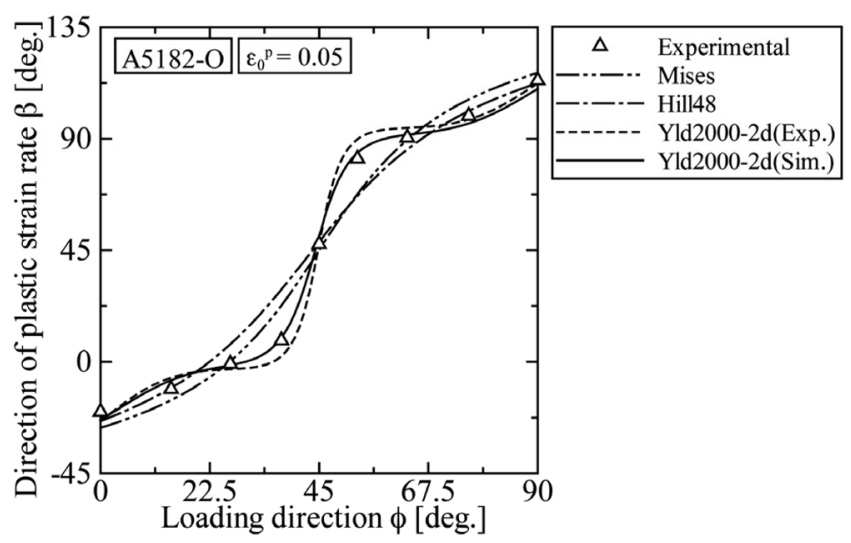

Fig. 13 Comparison of directions of plastic strain rates calculated by the identified yield functions with those measured by the experimental biaxial tensile test.

\section{ラメータを示す。}

Fig. 12 に, 基準塑性ひずみ $\varepsilon_{0}^{p}=0.05$ における等塑性仕事点 の実験值と上記 4 種類の降伏関数から計算される理論降伏曲 面を示す。さらに, 各降伏関数の法線則を検証するために, Fig. 13 において各応力経路における塑性ひずみ速度の方向 の実験值と各降伏曲面の外向き法線べクトルの方向を比較 する。降伏曲面の再現精度が最も優れているのはYld20002d (Exp.) であるのに対し, 塑性ひずみ速度の方向については Yld2000-2d（Sim.）が実験值を最もよく再現していることが わかる。

\section{8. 液圧バルジ成形シミュレーション}

\section{1 シミュレーション条件}

前章で示した 4 種類の降伏関数を用いて液圧バルジ成形シ ミュレーションを行い, 得られたシミュレーション結果と実 験結果を比較することによって, 本研究で同定した材料モデ ルの妥当性を検証する。液圧バルジ成形シミュレーションに 用いた解析条件は文献 ${ }^{6)}$ と同様であり, 異なる条件のみ以 下に述べる。

Fig. 14 にミュレーションに用いた有限要素モデルを示 す。本研究ではメッシュ分割ソフトはHyper Mesh Ver. 10.0,

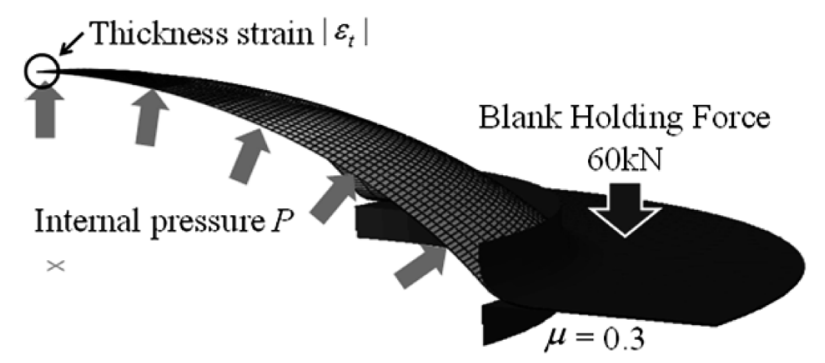

Fig. 14 Schematic illustration of finite element model for the hydraulic bulge forming simulation.

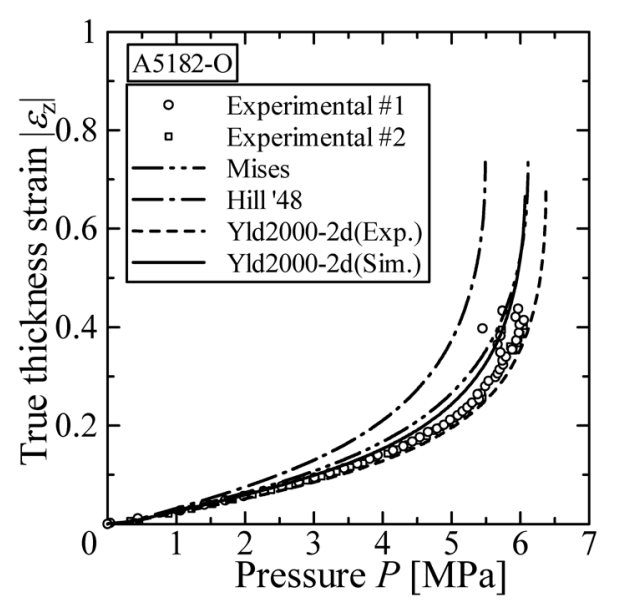

Fig. 15 Thickness strain-pressure curves simulated using the identified yield functions, compared with the experimental result.

有限要素解析ソルバはAbaqus/Standard Ver. 6.13-2を使用し た。降伏関数の導入にはユーザーサブルーチンUMATを用 いた。また, 板押え力を $60 \mathrm{kN}$, 素板とダイとの摩擦係数を 0.3 に設定した。シミュレーションにおいては, 実験と同じ 条件で素板の裏面に内圧を負荷した。シミュレーションは, 1 計算ステップの内圧増分が $10^{-10} \mathrm{MPa}$ 以下にしなければ計算 が収束しなくなる最大内圧まで実施した。そして, 成形中の 素板頂点部の板厚ひずみを算出し, 実験結果と比較する。な お, 本研究で用いた液圧バルジ試験方法や試験装置は, 文 献 6) で使用されたものと同一である。

\section{2 シミュレーション結果と考察}

Fig. 15 に, 液圧バルジ成形試験および液圧バルジ成形シ ミュレーションにより得られた素板の頂点部での板厚真ひず み-内圧曲線を示す。図中のプロットが実験值であり, 実線 はYld2000-2d（Sim.）を用いて得られたシミュレーション結 果を表す。また，二点鎖線で示した結果はvon Mises，一点 鎖線はHill'48, 破線はYYld2000-2d（Exp.）を用いて得られた シミュレーション結果を示している。 MisesやHill'48を用い たシミュレーションにおいては, 計算值は実験值よりも過大 に予測しており, 特にHill'48においては実験值との差異が顕 著である。これに対して, Yld2000-2d（Exp.) を用いたシミュ レーションにおいて, 変形初期から内圧が $P=6 \mathrm{MPa}$ に至るま での板厚ひずみの変化を最も良好に再現したことがわかる。 一方, 数值二軸引張試験による材料モデリング手法によって 同定したYld2000-2d（Sim.）を用いたシミュレーションにお いても, 内圧が $P=5 \mathrm{MPa}$ 以下となる範囲においては, 実験值 
よりもやや過大に予測する結果ではあるが，良好な再現精度 を得られることがわかる。また，内圧が $P=5 \mathrm{MPa}$ 以上におい ては，内圧の増大とともに実験結果との乘離も増大する傾向 にはあるが，Yld2000-2d（Exp.）と同程度の予測が可能であ ることは興味深い。

上述のように，液圧バルジ成形中の素板頂点部の板厚ひず みの変化の予測精度は, 内圧が $P=5.5 \mathrm{MPa}$ 以下となる範囲に おいては, Yld2000-2d (Exp.), Yld2000-2d（Sim.), Mises, Hill'48を用いたシミュレーション結果の順に高い。これは, 液圧バルジ成形において，素板は等二軸引張および平面ひず み引張の応力状態で変形することを考慮すれば, Fig. 12で示 した各降伏関数で計算される降伏曲面のうち平面ひずみ引張 から等二軸引張方向の範囲の予測精度に対応した結果である と考える。

数值二軸引張試験の結果に基づき同定される降伏関数を用 いた成形シミュレーションの予測精度を向上させるために は, 当然ながら数值二軸引張試験の予測精度を向上させなけ

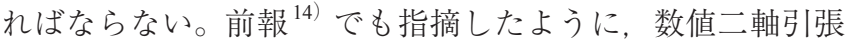
試験の予測精度向上のためには，EBSDで測定された集合組 織を定量的に再現する初期結晶方位デー夕を抽出する必要が ある。しかしながら，Fig. 4 に示した数值二軸引張試験に使 用した初期結晶方位デー夕は，その条件を十分に満たすもの ではなく，Tóthら ${ }^{22)}$ が提案するような供試材の集合組織の 特徵を適切に表現できる結晶方位の抽出方法を採用する必要 がある。さらに，供試材が呈した異方硬化挙動を正確に再現 しうる結晶塑性構成式の検討も必要である。これらについて は, 今後の研究課題としたい。

\section{9. 結言}

本研究では，均質化結晶塑性有限要素法を用いた数值二軸 引張試験による材料モデリング方法を提案した。本手法を アルミニウム合金板A5182-O材の材料モデリングに適用し, 数值二軸引張試験とその計算結果に基づく降伏関数の同定を 行った。さらに, 同定した降伏関数を用いて液圧バルジ成形 シミュレーションを実施した。数值二軸引張試験および液圧 バルジ成形シミュレーションの計算結果を, 十字形試験片を 用いた二軸引張試験と液圧バルジ成形試験の実験結果と比較 することによって，本研究で提案する材料モデリング手法の 妥当性を検証した。その結果，以下の知見を得た。

(1) 数值二軸引張試験により得られる等塑性仕事面の計算 值は実験值を良好に再現し，その計算值に基づいて同定した Yld2000-2d 降伏関数は, Misesの降伏関数や Hill'48 降伏関数 よりも，等塑性仕事面の形状変化および塑性ひずみ速度の方 向の実験值を良好に再現することができる。

(2) 数值二軸引張試験の計算結果に基づいて同定した Yld2000-2d 降伏関数を液圧バルジ成形シミュレーションに導 入することによって, Misesの降伏関数や Hill'48 降伏関数よ りも良好に実験結果を再現することができ，その予測精度は
十字形試験片を用いた二軸引張試験の結果に基づき同定した Yld2000-2d 降伏関数と同程度である。

（3）数值二軸引張試験による材料モデリング方法によっ て，成形シミュレーションの高精度化を実現するためには， 数值二軸引張試験の予測精度向上が必要である。そのために は，数值二軸引張試験において入力データとなる結晶方位の 抽出方法の改善および供試材の異方硬化挙動を正確に再現で きる結晶塑性構成式の選定が必要である。

(4) 数值二軸引張試験および実験的な二軸引張試験による 材料モデリング方法の双方を確立することで，所与の板材の 変形挙動をより高精度に再現する適切な降伏関数を同定可能 となり, 成形シミュレーションの予測精度向上に貢献する解 析技術となると考える。

本研究は, 軽金属学会「成形性評価シミュレーションに関 する基盤技術開発」研究部会の共同研究の一環として行われ た。貴重な御議論を頂いた委員各位に対して, ここに記して 謝意を表する。また, 本研究の一部は, 科学研究費補助金若 手研究（A）（課題番号：25709002）の補助のもと実施した。

\section{参 考 文 献}

1）胡 建国，石川孝司：軽金属，48（1998），540-547.

2) 福永良太, 小池正俊：塑性と加工，46（2005），590-594.

3) 林 央：塑性と加工, 44 (2003), 2-6.

4) 桑原利彦：塑性と加工, 54 (2013), 18-24.

5) T. Kuwabara, S. Ikeda and K. Kuroda: J. Mater. Proc. Tech., 80-81 (1998), 517-523.

6) 彌永大作, 桑原利彦, 上間直幸, 浅野峰生：軽金属, 62 (2012), $7-13$.

7) 川口順平, 桑原利彦, 櫻井健夫：軽金属, 65 (2015), 554-560.

8) F. Barlat, J. C. Brem, J. W. Yoon, K. Chung, R. E. Dick, D. J. Lege, F. Pourboghrat, S. H. Choi and E. Chu: Int. J. Plast., 19 (2003), 12971319.

9) D. Yanaga, T. Kuwabara, N. Uema and M. Asano: Int. J. Solid. Struct., 49 (2012), 3488-3495.

10) E. Nakamachi, C. L. Xie, H. Morimoto, K. Morita and N. Yokoyama: Int. J. Plast., 18 (2002), 617-632.

11) C. L. Xie and E. Nakamachi: Mater. Des., 23 (2002), 59-68.

12) D. Raabe, Y. Wang and F. Roters: Comput. Mater. Sci., 34 (2005), 221-234.

13) M. Kraska, M. Doig, D. Tikhomirov, D. Raabe and F. Roters: Comput. Mater. Sci., 46 (2009), 383-392.

14) 橋本圭右, 山中晃徳, 川口順平, 櫻井健夫, 桑原利彦 : 軽金属, 65 (2015), 196-203.

15) D. Peirce, R. J. Asaro and A. Needleman: Acta Metall., 30 (1983), 1087-1119.

16) J. Pan and J. R. Rice: Int. J. Solid. Struct., 19 (1983), 973-987.

17) J. W. Hachinson: Proc. R. Soc. Lond. A, 319 (1970), 247-272.

18) R. J. Asaro: Adv. Appl. Mech., 23 (1983), 1-115.

19) H. Kuramae, Y. Ikeya, H. Sakamoto, H. Morimoto and E. Nakamachi: Int. J. Mech. Sci., 52 (2010), 183-197.

20) J. M. Guedes and N. Kikuchi: Comput. Methods Appl. Mech. Eng., 83 (1990), 143-198

21) Y. Higa and Y. Tomita: Proc. The 8th International Conference on Mechanical Behavior of Materials, Vol. III, (1999), 1095-1099.

22) S. Tóth and P. V. Houtte: Text. Microstruct., 19 (1992), 229-244. 